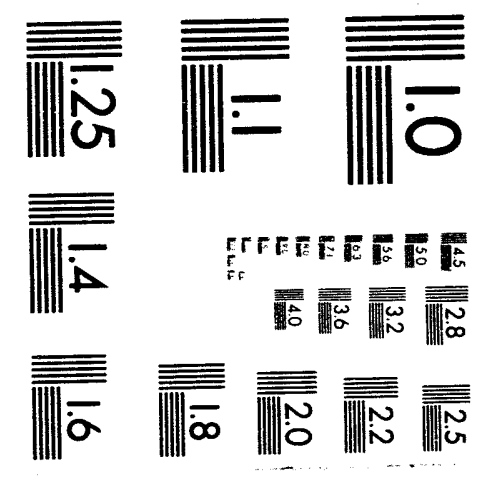



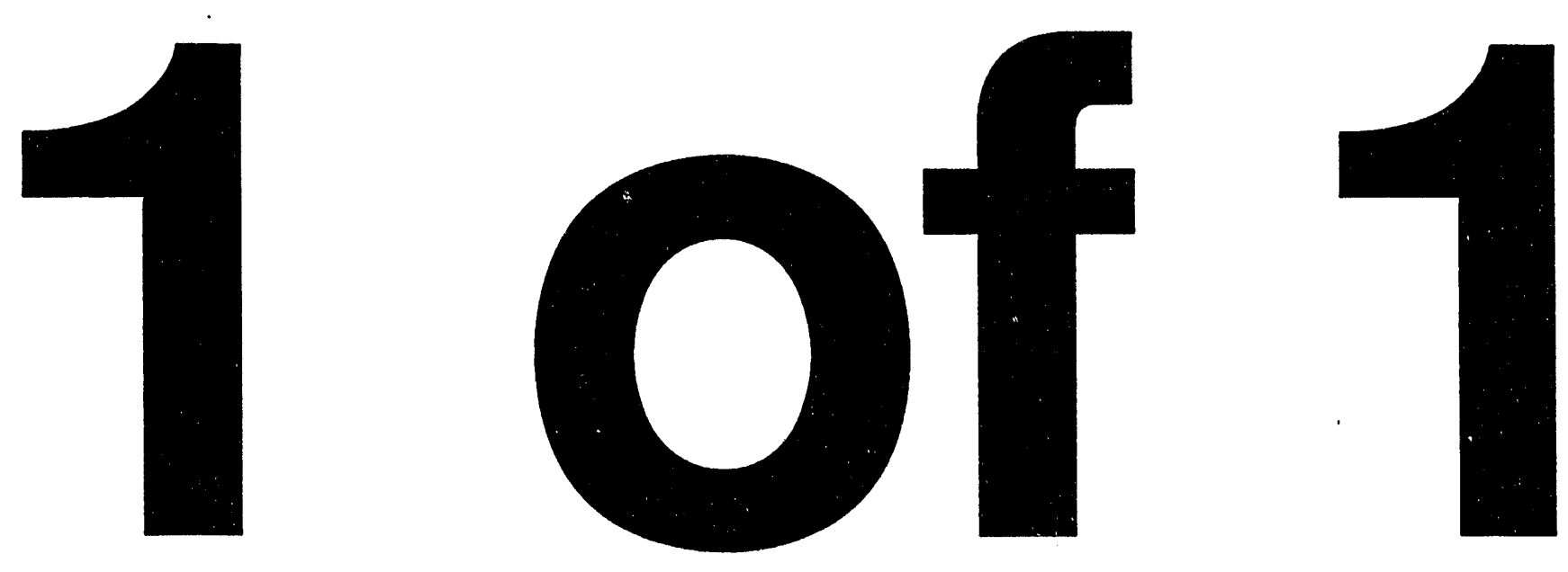


\section{Lower Three Runs Instream Flow Study (U)}

B. R. del Carmen and M. H. Paller

Westinghouse Savannah River Company

Savannah River Site

Aiken, SC 29808

Prepared for the U.S. Department of Energy under contract no. DE-AC09-89SR18035 


\section{Disclaimer}

This report was prepared as an account of work sponsored by an agency of the United States Government. Neither the United States Government nor any agency thereof, nor any of their employees, makes any warranty, express or implied, or assumes any legal liability or responsibility for the accuracy, completeness, or usefulness of any information, apparatus, product, or process disclosed, or represents that its use would not infringe privately owned rights. Reference herein to any specific commercial product, process, or service by trade name, trademark, manufacturer, or otherwise does not necessarily constitute or imply its endorsement, recommendation, or favoring by the United States Government or any agency thereof. The views and opinions of authors expressed herein do not necessarily state or reflect those of the United States Government or any agency thereof. 
Rev 0

\section{Lower Three Runs Instream Flow Study (U)}

B. R. del Carmen and M. H. Paller

Westinghouse Savannah River Company

Savannah River Site

Aiken, SC 29808

Prepared for the U. S. Department of Energy under contract No. DE-AC09-89SR 18035 


\title{
Contents
}

\author{
Abstract 1 \\ Executive Summary 1 \\ Introduction 1 \\ Study Site 2 \\ Methods 2
}

Field Measurements 2

WSP 2

AVDEPTH 3

Results and Observations 3

WSP Model Calibration 3

AVDEPTH Habitat Simulation 3

Discharge Recommendations and Effects on Fish Community 3

Conclusions 5

References 5

Tables 6

Figures 10 


\title{
Lower Three Runs Instream Flow Study (U)
}

\author{
B. R. del Carmen and M. H. Paller
}

\section{Abstract}

An Instream Flow Study was conducted to identify the minimum discharge from PAR Pond that will support a balanced biological fish community in Lower Three Runs. Hydraulic and habitat models of the Physical Habitat Simulation System (PHA.BSIM), the major component of the U.S. Fish and Wildlife Service's Instream Flow Incremental Methodology (IFIM) were applied. Following calibration of the Water Surface Profile (WSP) Model for three study reaches, hydraulic data was input to the AVDEPTH habitat model to develop relationships between discharge and available habitat.

\section{Executive Summary}

An instream flow study was performed on Lower Three Runs to identify a discharge rate from PAR Pond that will protect aquatic life in the stream and allow for the reduction of pumping water inflows to PAR Pond. The Physical Habitat Simulation (PHABSIM) system of the U.S. Fish and Wildlife Service's (USFWS) Instream Flow Incremental Methodology (IFIM) was used to develop the habitat vs. discharge relationships. Under high and low-flow conditions, measurements of water surface elevation, discharge, and velocity were taken in three reaches: Road B, Donora Station, and Patterson Mill. Following calibration, the Water Surface Profile (WSP) model was used to simulate water surface elevations for a range of discharges at each reach. The AVDEPTH habitat model produced depth, width, cross sectional area, and velocity data for different discharges. Simulated depths and velocities were compared with a sample of depth and velocity data measured in variously sized SRS streams. From this analysis, it is concluded that a base flow of $10 \mathrm{cfs}$ in the reach of Lower Three Runs below the PAR Pond dam is sufficient to support a biologically balanced fish community commensurate with a first/second order stream community.

\section{Introduction}

The flow in Lower Three Runs has been regulated by the discharge from PAR Pond since 1958, the year the PAR Pond dam was constructed. Discharge to Lower Three Runs has varied over the years due to changes in reactor operation and water levels in PAR Pond (Figure 1). The U. S. Geologic Survey (USGS) has measured flow in Lower Three Runs below the dam (USGS $\# 02197380$ ) and at Patterson Mill (USGS \#02197400) since Water Year (October-September) 1974 (Station below PAR Pond did not operate during Water Years 1983-1986.). The average flows below the dam and at
Patterson Mill for the periods of record are 37 cubic feet per second (cfs) and $85 \mathrm{cfs}$ respectively. Excluding the years when the station below the dam was not operational, the average flow at Patterson Mill is $87 \mathrm{cfs}$.

Since $P$ Reactor is no longer operating, it is not necessary to operate PAR Pond as a recirculating cooling system. Consequently, it is possible to significantly reduce operating costs by pumping less water into PAR Pond. This action would then reduce the discharge of water to Lower Three Runs. Reduction in Lower Three Runs flow could have substantial impacts on the aquatic life and habitat indices such as depth, cross sectional area, and velocity. The greatest impacts to Lower Three Runs are expected in the reach of stream immediately downstream from the dam where flow is almost entirely regulated by PAR Pond discharge.

The optimal solution to this problem is the determination of a discharge rate that will protect the aquatic life as well as reduce the costs associated with pumping river water to the PAR Pond/Lower Three Runs system. This solution is obtained by use of the U.S. Fish and Wildlife Service's (USFWS) Instream Flow Incremental Methodology (IFIM), a method designed to assist in the resolution of instream flow issues. The primary component of the IFIM is the Physical Habitat Simulation (PHABSIM) system, a combination of both hydraulic and habitat simulation models. PHABSIM uses simulated hydraulic data such as depth and velocity with channel indices such as cover or substrate as input to various habitat simulation models to develop a relationship between discharge and habitat availability. Several different hydraulic and habitat models are available for the development of this relationship. Based on available data and prior experience, the study designer must select the best modeling approach for each individual study. 
The objective of this study is to incorporate discharge, depth, and velocity data collected in Lower Three Runs into the PHABSIM system to develop a relationship between discharge and available habitat. This relationship will be used to identify a discharge rate from PAR Pond that will adequately protect the aquatic life in Lower Three Runs.

\section{Study Site}

The study site consists of the region of Lower Three Runs extending from the PAR Pond outfall downstream to Patterson Mill. Within the study site three study reaches were selected: Road B, Donora Station, and Patterson Mill (Figure 2). Donora Station is approximately 1 mile downstream from Road B and Patterson Mill is approximately miles downstream from Donora Station. The reaches were selected based on their accessibility by road or trail. The respective reach lengths for Road B, Donora Station, and Patterson Mill are 654, 243, and $252 \mathrm{ft}$. Within each study reach, transects were established. These transects are the actual locations where measurements were taken (i.e. water surface elevation, bed elevation profile, and velocity profile). Nine, four, and five transects were located in Road B, Donora Station, and Patterson Mill reaches respectively. The reaches are dominated by runs, but sections of deep pools (3-4 ft) do occur in each of the three reaches. The substrate is primarily coarse sand with silt/sand occurring in the pools.

\section{Methods}

\section{Field Measurements}

A single reference stake was set at each transect. The stakes were surveyed by BSRI (Bechtel Savannah River, Inc.) Layout to determine reference elevations. All survey loops were closed to ensure accurate measurements. Surveyed elevations at the Road B reach are referenced to National Geodetic Vertical Datum (NGVD). Surveyed elevations at the Donora Station and Patterson Mill reaches are relative elevations due to the absence of vertical benchmarks in the reach areas.

Measurements at each transect included water surface elevation, depth profile, and velocity profile. Transect measurements were performed by personnel from the Environmental Sciences Section. Bed elevations were computed by subtracting stream depths from water surface elevation. Transect discharges were computed from the velocity measurements. Water surface elevations were measured with a Spectra LSR Laser
Level System. Velocities were measured with a Marsh McBirney 201D Digital Current Meter attached to a standard top-setting wading rod. Mean column velocities were measured at $0.6 \times$ mean column depth for depths less than $1.5 \mathrm{ft}$ and at $0.2 \times$ mean column depth and $0.8 \times$ mean column depth for depths greater than or equal to $1.5 \mathrm{ft}(0.2$ and 0.8 velocities were averaged).

Measurements were made under two flow conditions: low and high. Table 1 shows the average measured discharges at the three reaches for the two flow conditions. Figure 3 depicts a representative cross section at each of the three reaches under both flow conditions. The low flow condition was represented by discharge from the dewatering system for the dam seepage repair. At the most upstream reach, Road B, the low flow averaged $2.3 \mathrm{cfs}$. The high flow condition was represented by the discharge associated with the operation of one-half of a siphon. This high flow is the minimum flow that can be discharged through the PAR Pond siphon system. The high flow at the Road B reach averaged $40 \mathrm{cfs}$. Due to the limitations of the PAR Pond siphon system it was not possible to obtain measurements for flow conditions between these two extremes.

\section{WSP}

The Water Surface Profile (WSP) hydraulic model provides a method of simulating depths, widths, velocities, and water surface elevation within a cross section for a specified range of discharges with one set of field data. The water surface elevation data is required as input to the AVDEPTH habitat simulation model. Hydraulic relationships in the WSP model are defined by the energy balance and mass balance concepts. The use of these concepts requires iwo assumptions: steady flow conditions and rigid boundary conditions. Data required for model calibration includes a discharge, water surface profile, and velocity profile at each transect. Model calibration is obtained in two steps: calibration of water surface elevations and calibration of velocities. Initial calibration of the water surface elevations involves adjusting the roughness factor ( $n$ ) for all cells within a transect until the simulated profile agrees with the measured profile. In the second step of calibration the roughness factors in the individual cells are adjusted until simulated cell velocities agree with measured velocities while keeping water surface elevations within the calibration limits. The usual calibration standards are $\pm 0.1 \mathrm{ft}$ for water surface elevations and $上 0.2 \mathrm{ft} / \mathrm{sec}$ for velocities. The extrapolation range for a calibrated data set is 
generally recommended as $40-250 \%$ of the calibrated discharge (Milhous et al. 1989).

\section{AVDEPTH}

Wetted width, depth, and average velocity have long been used as indicators of instream physical habitat. The AVDEPTH habitat simulation program produces complete hydraulic data for each transect and a summary of the average parameters for the entire reach. Cross sectional data and water surface elevations are required input to the AVDEPTH model. Output includes width, depth, area, velocity, wetted perimeter, and cross-sectional data. For each specified depth (maximum of 5) the AVDEPTH program can also calculate the total width of a stream cross section that is at least as deep as the specified depth (Milhous et al. 1989).

\section{Results and Observations}

\section{WSP Model Calibration}

The WSP model was calibrated to water surface elevations and cell velocities for the high discharge at all three reaches. Roughness modifiers were then added to the calibrated data sets to attempt calibration of the low flow condition. Usually, roughness increases as discharge decreases due to increased friction and a higher percentage of instream cover. With the roughness modifiers, all simulated low flow water surface elevations in the Donora Station and Patterson Mill reaches were within the calibration limit of $\pm 0.1 \mathrm{ft}$ and average simulated transect velocities were within $0.2 \mathrm{ft} / \mathrm{sec}$ of the average measured transect velocities. Water surface elevation calibration could not be obtained for the Road B reach. This is consistent with several previous studies that show the difficulty in calibrating the WSP model at low-flow conditions. During low discharges, flow conditions can change quickly, alternating between riffles and pools. Under these conditions, the assumption of gradually varied flow does not apply (Osborne et al. 1988).

The WSP model was run with the calibrated data sets to determine water surface elevations for a range of discharges at each reach. Becaise the regulated historical average flow below PAR Pund is $37 \mathrm{cfs}$ and future discharges would be equal to or less than this quantity, it was not necessary to simulate discharges above the high flow condition. For the Road B reach, water surface elevations were simulated for discharges less than the recommended lower extrapolation limit $(16 \mathrm{cfs})$ to determine if the low-flow depths simulated by the AVDEPTH routine would significantly differ from measured depths. These results are discussed in the following section.

\section{AVDEPTH Habitat Simulation}

Water surface elevation data produced by the WSP model was input to the AVDEPTH routine to develop relationships between discharge and channel characteristics such as depth and velocity. The Road B reach data for discharge vs. depth and discharge vs. velocity were fitted with a second-order polynomial curve. The Donora Station and Patterson Mill data were fitted with third-order polynomial curves. Tables 2-4 present the average stream predicted parameters for the three reaches under different discharges. Predicted discharge vs. depth relationships are shown in Figures 4-6. Predicted discharge vs. velocity relationships are presented in Figures 7-9. For comparison, upper quantile $(90 \%)$, upper quartile $(75 \%)$, median $(50 \%)$, lower quartile $(25 \%)$, and lower quantile $(10 \%)$ depths and velocities measured in 18 first and second order SRS streams during periods of base flow are also shown in the figures representing Road B and Donora Station. Average simulated depth $(0.55 \mathrm{ft})$ and average measured depth $(0.51 \mathrm{ft})$ in the Road B reach at the low flow condition are in close agreement. This indicates that despite an inability to calibrate the WSP model at the low flow, average reach depth is accurately simulated.

\section{Discharge Recommendations and Effects on Fish Community}

Fish assemblages in SRS streams are strongly affected by depth, width, and current velocity (Meffe and Sheldon 1988, Paller 1992) as is typical of stream fish assemblages in general. These variables, in turn, are determined by discharge. Substantial reductions in discharge in Lower Three Runs can be expected to have substantial effects on fish community structure. If discharge decreases to the extent that habitat becomes unsuitable for most fish the resulting changes in fish community structure will be deleterious (e.g., large reductions in number of fish species). Lesser reductions in discharge that produce lesser changes in depth and current velocity will cause changes in species composition as the fish community changes from one characteristic of large streams to one characteristic of small streams. Such changes are not necessarily negative if one accepts the proposition that the communities that inhabit small streams are as valuable as those that inhabit large streams. 
The WSP and AVDEPTH models were used to predict the depths, widths, and current velocities associated with different discharges. Information on the relationship between fish community structure and stream depth, width, and current velocity was then incorporated to predict the types of fish communities that would occur at these discharges. This approach differs from typical instream flow studies in that the focus was placed on the habitat requirements of entire fish assemblages rather than the habitat requirements of individual species. This was possible because of the large amount of information concerning habitat and fish assemblage structure in SRS streams. Also, discharge related changes in bottom substrate were not extensively dealt with because the substrate was uniform (primarily sand) and unaffected by changes in depth, width, and current velocity. Nor were discharge related changes in instream cover extensively dealt with (primarily submerged brush, snags, and logs) because preliminary analyses indicated that the quantity of instream cover was not consistently related to changes in discharge.

The smallest headwater streams are termed first order; stream order is increased whenever two streams of the same order unite. Stream order and stream size (represented by cross-sectional area) are strongly correlated, and from a biological perspective, measurements of much the same phenomena (Paller 1993). The species that occur in first and second order streams differ markedly from those that occur in fourth order streams. Assemblages in third order streams are intermediate in composition. The most abundant fish in first and second order SRS streams are yellowfin shiner, bluehead chub, pirate perch, tessellated darter, several species of madtom, and dollar sunfish while the most abundant fish in fourth order streams are spotted sucker, largemouth bass, coastal shiner, dusky shiner, American eel, bluegill, and redbreast sunfish (Table 5). These differences in assemblage structure are largely determined by depth and width related differences among stream orders (Paller 1993). Depths, widths, and current velocities in SRS streams of different orders during base flow periods (late summer and fall) during years of typical rainfall (Savannah River Technology Center Weather Center 1993) are shown in Table 6.

Figure 4 depicts the relationships between discharge and depth in Lower Three Runs near Road B as predicted by the WSP and AVDEPTH models. The relationship between discharge and velocity in Lower Three Runs at Road B is shown in Figure 7. A discharge of approximately $30 \mathrm{cfs}$ would produce depths near Road B equivalent to the median depth during base flow periods for third order SRS streams
(Figure 4 and Table 6). A discharge of approximately $13 \mathrm{cfs}$ would produce depths equivalent to the median depth during base flow periods for second order streams. A discharge of $10 \mathrm{cfs}$ would produce depths that are less than those in the typical (i.e., median) second order stream but greater than those in over $25 \%$ of the second order streams measured on SRS (Figure 4 and Table 6). Further, a discharge of $10 \mathrm{cfs}$ would result in current velocities below those in $75 \%$ of the second order streams but greater than those in $10 \%$ of the second order streams (Figure 7 and Table 6). Because the channel of Lower Three Runs is relatively wide, all of the aforementioned discharges would result in stream widths greater than in typical second order streams (Tables 2 and 6). Presumably, with time, the bed of Lower Three Runs will equilibrate to lower flows resulting in a somewhat deeper and narrower channel.

To create conditions that support typical third order stream fish communities in Lower Three Runs near Road B would necessitate discharges in the range of $25-30 \mathrm{cfs}$ as discussed above. Assuming that most or all of the stream flow at Road B comes from PAR Pond, this would necessitate water releases from PAR Pond (hence pumping rates from the Savannah River) only slightly below those that have historically occurred ( 37 cfs). It may be more practical from an economic perspective to create conditions that will support a first/second order stream fish community. Such communities are comparatively diverse and are a naturally occurring part of the SRS ecosystem. Because they are diverse, naturally occurring, self maintaining and consist of indigenous species, they satisfy the Clean Water Act definition of a Balanced Biological Community. A base flow stream discharge as low as 10 cfs should be sufficient to create conditions that will support a first/second order stream fish community. While a discharge of $10 \mathrm{cfs}$ will produce depths and particularly current velocities somewhat lower than is typical, these important habitat variables will be above the minimum for first and second order streams

The criterion of $10 \mathrm{cfs}$, developed on the basis of conditions near Road B, is also sufficient to support first/second order fish communities further downstream. The measurements suggest that by the time Donora Station is reached, approximately $2.4 \mathrm{cfs}$ of natural flow will be added to whatever is released from PAR Pond. If $10 \mathrm{cfs}$ is released from PAR Pond during base flow periods, the total flow at Donora Station, approximately $12.4 \mathrm{cfs}$, should be sufficient to maintain a depth equal to or greater than the median depth for first/second order streams on SRS (Figure 5 and Table 6). As at Road B, current velocities would be 
lower than the median for first/second order streams but greater than in over $10 \%$ of the first/second order streams (Figure 8 and Table 6). Approximately 5 miles downstream from Road B at Patterson Mill, habitat quality is less strongly affected by PAR Pond discharge because of large natural flow contributions. Conditions at Patterson Mill will be sufficient to support second or even third order stream fish assemblages if PAR Pond discharge is maintained at $10 \mathrm{cfs}$ (Figure 3 and Table $6)$.

\section{Conclusions}

Based on discharge/habitat relationships predicted by commonly used instream flow models and information on fish assemblage structure in SRS streams, it is concluded that a base flow of $10 \mathrm{cfs}$ is sufficient to support a diverse and biologically balanced fish community in the reach of Lower Three Runs downstream from the PAR Pond Dam. Assuming that water released from PAR Pond constitutes all stream discharge immediately below the dam, this equates to a minimum release of $10 \mathrm{cfs}$ from PAR Pond.

\section{References}

Meffe, G.K., and A.L. Sheldon, (1988), The influence of habitat structure on fish assemblage composition in southeastern blackwater streams, American Midland Naturalist 119:225-240.

Milhous, Robert T., Marlys A. Updike, and Diane M. Schneider, (1989), Physical Habitat Simulation System Reference Manual - Version II, Instream Flow Information Paper No. 26, National Ecology Research Center, Fish and Wildlife Service, Biological Report $89(16)$.

Osborne, Lewis L., Michael J. Wiley, and R. Weldon Larimore, (1988), Assessment of the Water Surface Profile Model: Accuracy of Predicted Instream Fish Habitat Conditions in Low-Gradient, Warmwater Streams, Regulated Rivers: Research and Management 2: 619-631.

Paller, M.H., (1993), Relationships between fish assemblage structure and stream order in South Carolina coastal plain streams. In press. Transactions of the American Fisheries Society.

Savannah River Technology Center Weather Ceniter, (1993), Meteorological Monthly Report for February 1993, Savannah River Technology Center, Aiken, SC. 


\section{Tables}

Table 1. Summary of average measured reach flows.

Road B

Donora Station

Patterson Mill
High (cfs)

40

43

55
Low (cfs)

2.3

4.7

24 
Table 2. Road B predicted data for different discharges.

\begin{tabular}{|c|c|c|c|c|c|c|c|c|c|c|}
\hline \multirow[b]{2}{*}{$\begin{array}{l}Q \\
(c f s)\end{array}$} & & \multicolumn{5}{|c|}{ Width Witt LDepth Greater Than } & \multirow[b]{2}{*}{$\begin{array}{l}\text { Depth } \\
\text { (ft) }\end{array}$} & \multirow[b]{2}{*}{$\begin{array}{l}X-S e c \\
\text { Area } \\
(s q f t)\end{array}$} & \multirow[b]{2}{*}{$\begin{array}{l}\text { Velocity } \\
\text { (ft/sec) }\end{array}$} \\
\hline & $\begin{array}{l}\text { Wetted } \\
\text { Perimeter } \\
\text { (ft) }\end{array}$ & $\begin{array}{l}\text { Width } \\
\text { (ft) }\end{array}$ & $\begin{array}{l}0.5 \mathrm{ft} \\
(\mathrm{ft})\end{array}$ & $\begin{array}{l}i \mathrm{ft} \\
(\mathrm{ft})\end{array}$ & $\begin{array}{l}1.5 \mathrm{ft} \\
(\mathrm{ft})\end{array}$ & $\begin{array}{l}2 \mathrm{ft} \\
(\mathrm{ft}) \\
\end{array}$ & $\begin{array}{l}3 \mathrm{ft} \\
(\mathrm{ft})\end{array}$ & & & \\
\hline 5 & 26.63 & 26.00 & 10.57 & 2.79 & 1.36 & 0.96 & 0.45 & 0.54 & 14.20 & 0.35 \\
\hline 10 & 30.17 & 29.39 & 18.68 & 4.17 & 2.12 & 1.24 & 0.60 & 0.73 & 21.30 & 0.47 \\
\hline 13 & 31.58 & 30.73 & 20.71 & 6.93 & 2.48 & 1.34 & 0.66 & 0.80 & 24.60 & 0.53 \\
\hline 15 & 32.62 & 31.73 & 21.74 & 8.39 & 2.70 & 1.57 & 0.69 & 0.84 & 26.50 & 0.57 \\
\hline 17 & 33.23 & 32.30 & 23.88 & 11.07 & 2.92 & 1.76 & 0.72 & 0.89 & 28.70 & 0.59 \\
\hline 20 & 33.77 & 32.78 & 26.96 & 13.92 & 3.18 & 1.89 & 0.75 & 0.96 & 31.40 & 0.64 \\
\hline 22 & 33.98 & 32.96 & 27.97 & 15.45 & 3.37 & 1.96 & 0.76 & 1.00 & 33.10 & 0.66 \\
\hline 30 & 34.80 & 33.67 & 30.41 & 20.02 & 4.62 & 2.36 & 0.97 & 1.17 & 39.50 & 0.76 \\
\hline 35 & 35.33 & 34.13 & 31.59 & 21.57 & 8.87 & 2.70 & 1.06 & 1.27 & 43.20 & 0.81 \\
\hline 40 & 35.74 & 34.50 & 32.41 & 24.42 & 12.14 & 2.99 & 1.13 & 1.34 & 46.30 & 0.86 \\
\hline
\end{tabular}

Table 3. Donora Station predicted data for different discharges.

\begin{tabular}{|c|c|c|c|c|c|c|c|c|c|c|}
\hline \multirow[b]{2}{*}{$\begin{array}{l}Q \\
\text { (cfs) }\end{array}$} & & \multicolumn{5}{|c|}{ Width With Depth Greater Than } & \multirow[b]{2}{*}{$\begin{array}{l}\text { Depth } \\
\text { (ft) }\end{array}$} & \multirow[b]{2}{*}{$\begin{array}{l}X-S e c \\
\text { Area } \\
\text { (sq ft) }\end{array}$} & \multirow[b]{2}{*}{$\begin{array}{l}\text { Velocity } \\
\text { (ft/sec) }\end{array}$} \\
\hline & $\begin{array}{l}\text { Wetted } \\
\text { Perimeter } \\
\text { (ft) }\end{array}$ & $\begin{array}{l}\text { r Width } \\
\text { (ft) }\end{array}$ & $\begin{array}{l}0.5 \mathrm{ft} \\
\text { (ft) }\end{array}$ & $\begin{array}{l}1 \mathrm{ft} \\
(\mathrm{ft})\end{array}$ & $\begin{array}{l}1.5 \mathrm{ft} \\
\text { (ft) }\end{array}$ & $\begin{array}{l}2 \mathrm{ft} \\
(\mathrm{ft})\end{array}$ & $\begin{array}{l}3 \mathrm{ft} \\
(\mathrm{ft})\end{array}$ & & & \\
\hline 5 & 25.03 & 24.75 & 14.67 & 2.25 & 1.43 & 1.02 & 0.00 & 0.63 & 15.50 & 0.32 \\
\hline 7 & 27.40 & 27.04 & 19.27 & 5.09 & 1.57 & 1.15 & 0.00 & 0.72 & 19.50 & 0.36 \\
\hline 10 & 29.91 & 29.49 & 22.12 & 6.32 & 1.70 & 1.28 & 0.00 & 0.81 & 23.80 & 0.42 \\
\hline 12 & 32.18 & 31.72 & 23.38 & 11.24 & 1.78 & 1.35 & 0.00 & 0.84 & 26.50 & 0.45 \\
\hline 15 & 34.17 & 33.67 & 24.73 & 14.61 & 2.29 & 1.43 & 0.00 & 0.89 & 29.90 & 0.50 \\
\hline 17 & 35.17 & 34.64 & 25.72 & 16.42 & 2.68 & 1.48 & 0.00 & 0.93 & 32.20 & 0.53 \\
\hline 20 & 36.82 & 36.25 & 26.94 & 19.22 & 5.12 & 1.56 & 0.54 & 0.97 & 35.20 & 0.57 \\
\hline 22 & 38.37 & 37.77 & 27.67 & 20.57 & 5.46 & 1.60 & 0.61 & 0.98 & 37.10 & 0.59 \\
\hline 30 & 39.83 & 39.14 & 30.73 & 23.13 & 7.10 & 1.73 & 0.83 & 1.11 & 43.60 & 0.69 \\
\hline 37 & 42.22 & 41.44 & 33.63 & 24.70 & 14.74 & 2.36 & 0.98 & 1.17 & 48.60 & 0.76 \\
\hline 43 & 43.89 & 43.07 & 34.81 & 25.94 & 18.06 & 2.85 & 1.05 & 1.22 & 52.40 & 0.82 \\
\hline
\end{tabular}

Table 4. Patterson Mill predicted data for different discharges.

\begin{tabular}{|c|c|c|c|c|c|c|c|c|c|c|}
\hline \multirow[b]{2}{*}{$\begin{array}{l}Q \\
\text { (cfs) }\end{array}$} & & \multicolumn{5}{|c|}{ Width With Depth Greater Than } & \multirow[b]{2}{*}{$\begin{array}{l}\text { Depth } \\
\text { (ft) }\end{array}$} & \multirow[b]{2}{*}{$\begin{array}{l}\text { X-Sec } \\
\text { Area } \\
\text { (sq ft) }\end{array}$} & \multirow[b]{2}{*}{$\begin{array}{l}\text { Velocity } \\
\text { (ft/sec) }\end{array}$} \\
\hline & $\begin{array}{l}\text { Wetted } \\
\text { Perimete } \\
\text { (ft) }\end{array}$ & $\begin{array}{l}\text { Width } \\
\text { (ft) }\end{array}$ & $\begin{array}{l}0.5 \mathrm{ft} \\
(\mathrm{ft})\end{array}$ & $\begin{array}{l}1 \mathrm{ft} \\
(\mathrm{ft})\end{array}$ & $\begin{array}{l}1.5 \mathrm{ft} \\
(\mathrm{ft})\end{array}$ & $\begin{array}{l}2 \mathrm{ft} \\
(\mathrm{ft})\end{array}$ & $\begin{array}{l}3 \mathrm{ft} \\
(\mathrm{ft})\end{array}$ & & & \\
\hline 24 & 45.95 & 44.29 & 40.90 & 34.31 & 17.56 & 12.21 & 2.24 & 1.52 & 67.40 & 0.36 \\
\hline 27 & 46.29 & 44.57 & 41.52 & 37.42 & 19.75 & 12.71 & 2.45 & 1.59 & 71.00 & 0.38 \\
\hline 30 & 46.69 & 44.91 & 42.36 & 38.37 & 23.15 & 13.23 & 2.64 & 1.65 & 74.10 & 0.40 \\
\hline 32 & 46.88 & 45.07 & 42.59 & 38.73 & 23.99 & 13.65 & 2.88 & 1.68 & 75.90 & 0.42 \\
\hline 35 & 47.20 & 45.33 & 42.98 & 39.36 & 25.61 & 14.46 & 3.87 & 1.74 & 79.10 & 0.44 \\
\hline 37 & 47.37 & 45.47 & 43.19 & 39.74 & 26.71 & 15.00 & 4.31 & 1.78 & 81.00 & 0.46 \\
\hline 40 & 47.62 & 45.67 & 43.54 & 40.12 & 28.92 & 15.67 & 4.86 & 1.83 & 83.80 & 0.48 \\
\hline 43 & 47.91 & 45.89 & 43.99 & 40.55 & 30.53 & 16.31 & 5.33 & 1.90 & 87.00 & 0.49 \\
\hline 45 & 48.05 & 46.02 & 44.13 & 40.71 & 32.39 & 16.70 & 5.54 & 1.92 & 88.40 & 0.51 \\
\hline 47 & 48.25 & 46.18 & 44.31 & 40.91 & 34.35 & 17.58 & 5.82 & 1.95 & 90.20 & 0.52 \\
\hline 50 & 48.50 & 46.38 & 44.53 & 41.37 & 37.18 & 19.40 & 6.31 & 2.01 & 93.00 & 0.54 \\
\hline 55 & 48.81 & 46.61 & 44.94 & 42.40 & 38.39 & 23.17 & 7.13 & 2.08 & 97.20 & 0.57 \\
\hline
\end{tabular}


Table 5. Mean percent abundance of fish species in first, second, third, and fourth order streams on the South Carolina coastal plain (Paller 1993). Also shown are the results of one-way analyses of variance of the differences ${ }^{\mathrm{a}}$. Data were collected in late summer and fall of 1990 and 1992.

Stream order

\begin{tabular}{lrrrrr} 
Variable & $1 \& 2$ & 3 & 4 & F-test $^{\text {b }}$ & Probability \\
\hline & & & & & \\
Yellowfin shiner & $28.0^{\mathrm{a}}$ & 17.8 & 7.7 & 4.70 & 0.035 \\
Pirate perch & 23.1 & 9.4 & 3.1 & 39.22 & $<0.001$ \\
Bluehead chub & 8.7 & 7.1 & 0.4 & 8.27 & 0.006 \\
Creek chub & 1.9 & 0.2 & 0.0 & 17.18 & $<0.001$ \\
Dollar sunfish & 1.7 & 1.2 & 0.4 & 7.70 & 0.008 \\
Spotted sunfish & 2.1 & 7.5 & 4.4 & 2.62 & 0.112 \\
Bluegill & 0.8 & 1.1 & 2.9 & 5.78 & 0.020 \\
Tessellated darter & 1.7 & 2.2 & 0.2 & 3.87 & 0.055 \\
Yellow bullhead & 2.2 & 1.7 & 0.3 & 9.71 & 0.003 \\
Madtom & 3.2 & 2.1 & 0.9 & 4.29 & 0.044 \\
Creek chubsucker & 2.7 & 1.9 & 2.5 & 0.01 & 0.909 \\
Blackbanded darter & 0.6 & 1.8 & 1.9 & 4.10 & 0.049 \\
Redfin pickerel & 3.0 & 3.0 & 1.1 & 5.46 & 0.024 \\
Warmouth & 0.5 & 0.7 & 0.8 & 0.84 & 0.365 \\
Coastal shiner & 1.4 & 3.3 & 4.1 & 6.07 & 0.018 \\
Sailfin shiner & 1.3 & 0.6 & 5.7 & 4.76 & 0.441 \\
American eel & 0.6 & 2.5 & 6.3 & 35.59 & $<0.001$ \\
Largemouth bass & 0.4 & 1.2 & 7.1 & 26.47 & $<0.001$ \\
Chain pickerel & $<0.1$ & 1.2 & 2.5 & 28.76 & $<0.001$ \\
Redbreast sunfish & 3.8 & 7.3 & 7.1 & 4.33 & 0.043 \\
Spotted sucker & 0.0 & 0.5 & 12.4 & 60.37 & $<0.001$ \\
Dusky shiner & 5.4 & 6.1 & 15.0 & 5.17 & 0.028 \\
& & & & & \\
\hline
\end{tabular}

\footnotetext{
a Percents were arcsine transformed for analysis

b Degrees freedom for all tests equal 2,44

Source: (Paller 1993)
} 
Table 6. Depth, width, and current velocity in first through fourth order streams on SRS. First and second order streams were combined because of their similarity in size and current velocity. Measurements were taken during the late summer and fall of 1990 and 1992.

Depth (ft) Width (ft) $\quad \begin{gathered}\text { Current } \\ \text { velocity } \\ (\mathrm{ft} / \mathrm{s})\end{gathered}$

First and Second Order $(\mathrm{n}=18)$

\begin{tabular}{lrrr}
\hline Upper quantile & 1.32 & 22.29 & 1.26 \\
Upper quartile & 1.07 & 17.68 & 0.99 \\
Median & 0.79 & 9.89 & 0.69 \\
Lower Quartile & 0.66 & 8.12 & 0.57 \\
Lower Quantile & 0.41 & 6.64 & 0.26 \\
\hline
\end{tabular}

Third Order $(n=14)$

\begin{tabular}{llll}
\hline Upper quantile & 2.40 & 40.08 & 1.02 \\
Upper quartile & 1.89 & 25.10 & 0.88 \\
Median & 1.16 & 19.87 & 0.69 \\
Lower Quartile & 0.81 & 16.30 & 0.56 \\
Lower Quantile & 0.66 & 12.11 & 0.53 \\
\hline
\end{tabular}

Fourth Order $(n=15)$

\begin{tabular}{llll}
\hline Upper quantile & 3.88 & 49.68 & 1.39 \\
Upper quartile & 3.38 & 45.97 & 1.19 \\
Median & 3.05 & 32.09 & 0.98 \\
Lower Quartile & 2.76 & 25.79 & 0.85 \\
Lower Quantile & 1.73 & 18.94 & 0.52 \\
& & & \\
\hline
\end{tabular}

Source: (Unpublished data belonging to SRTC/ESS) 


\section{Figures}

Figure 1. Average annual regulated discharge rates in Lower Three Runs.

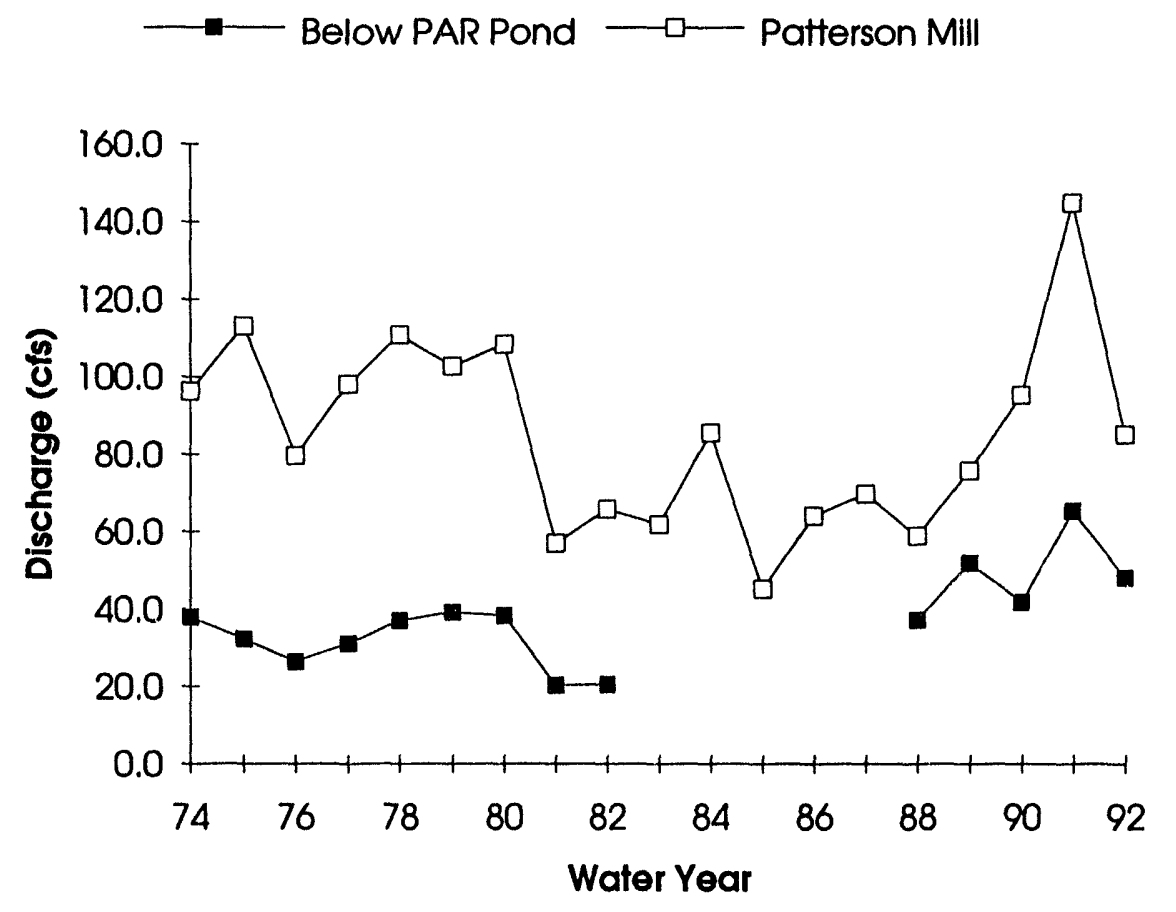


Figure 2. Study Site

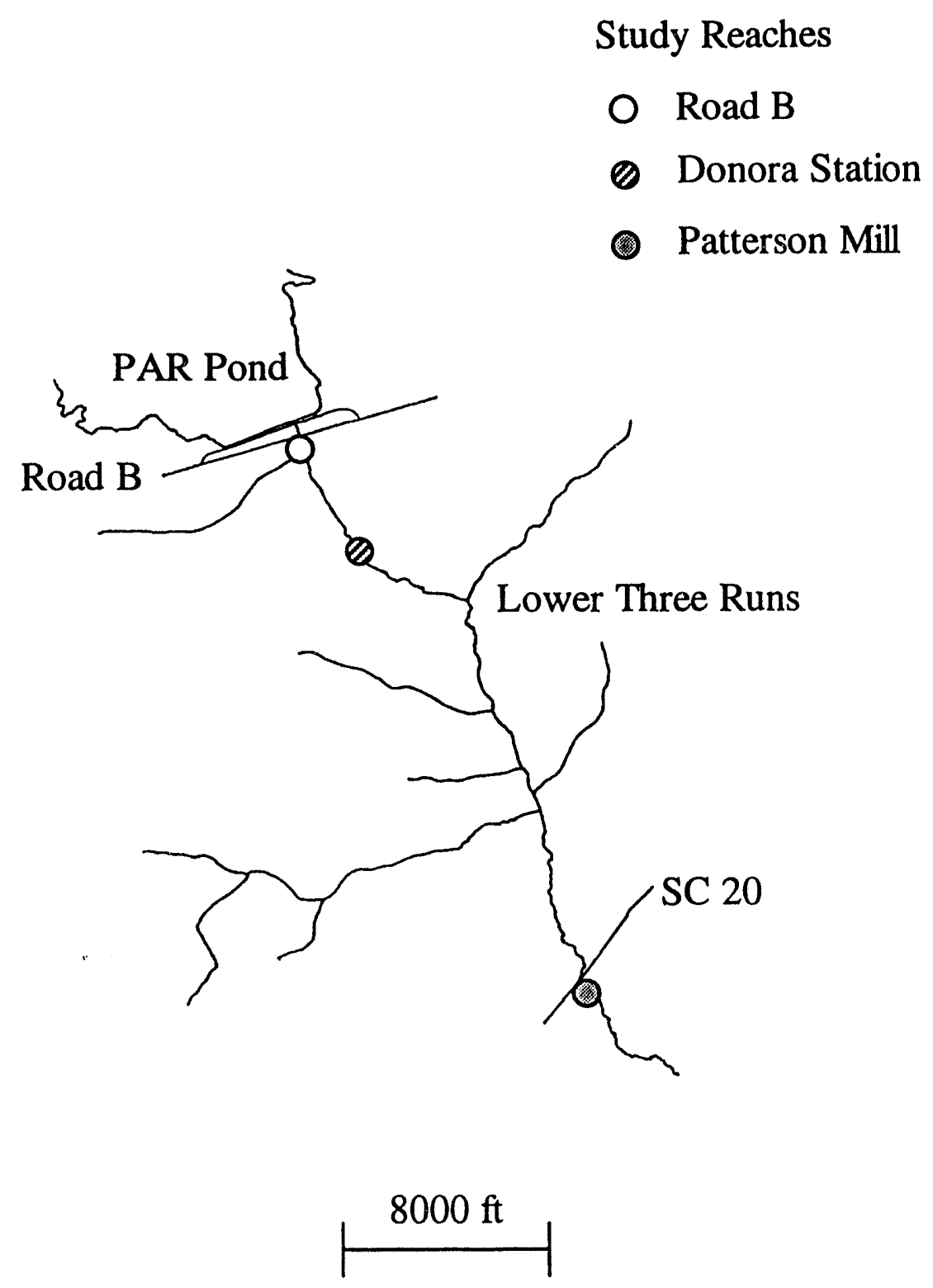


Figure 3. Representative Cross Sections at High (40 cfs) and Low (2.3) Discharges from PAR Pond.

R oad B : transect 2

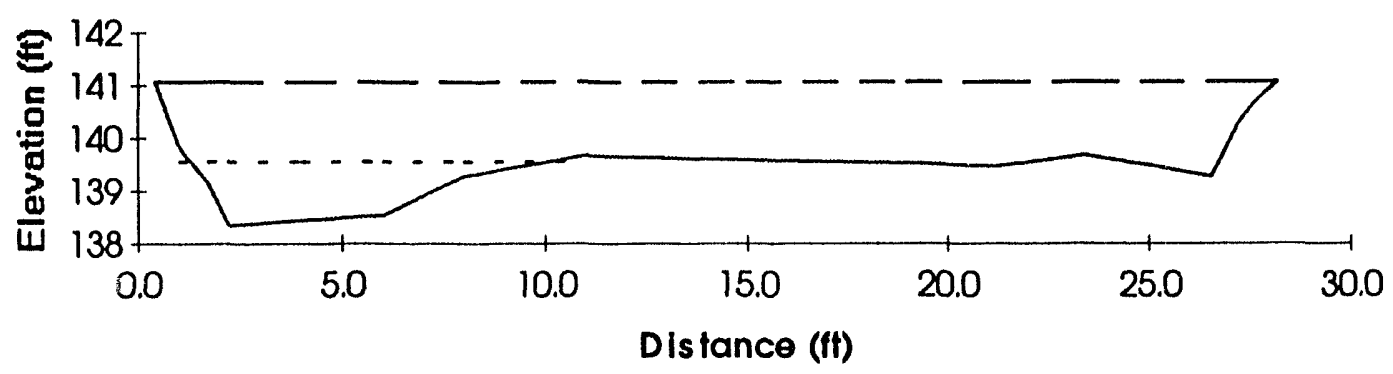

Donora S tation: transect 3

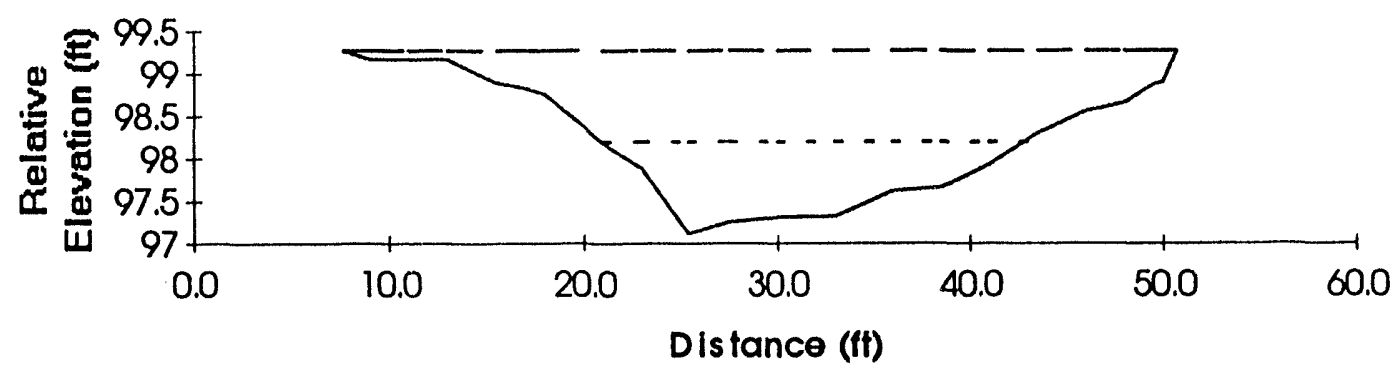

Patters on Mill: transect 1

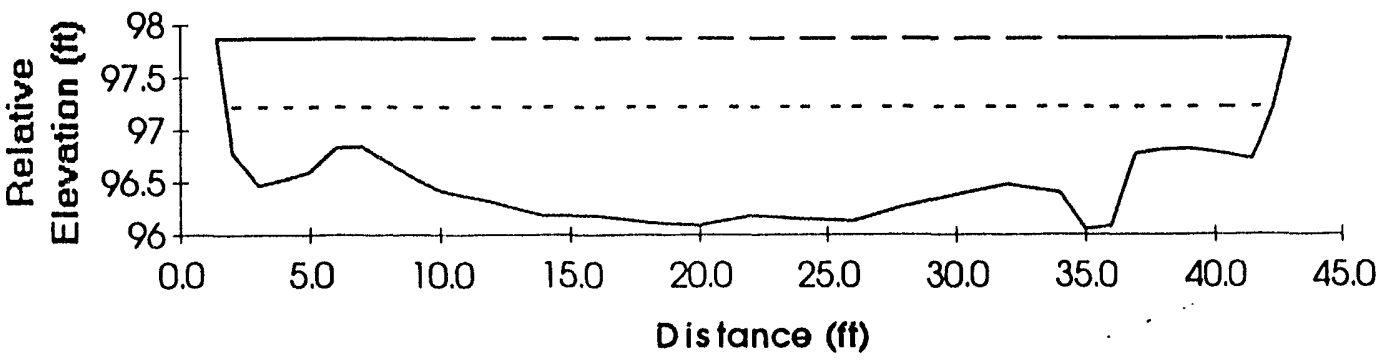


Figure 4. Predicted relationship between discharge and depth in Lower Three Runs at Road B. Also shown are median, upper quartile, upper quantile, lower quartile, and lower quantile depths measured during base flow periods in 18 first and second order SRS streams.

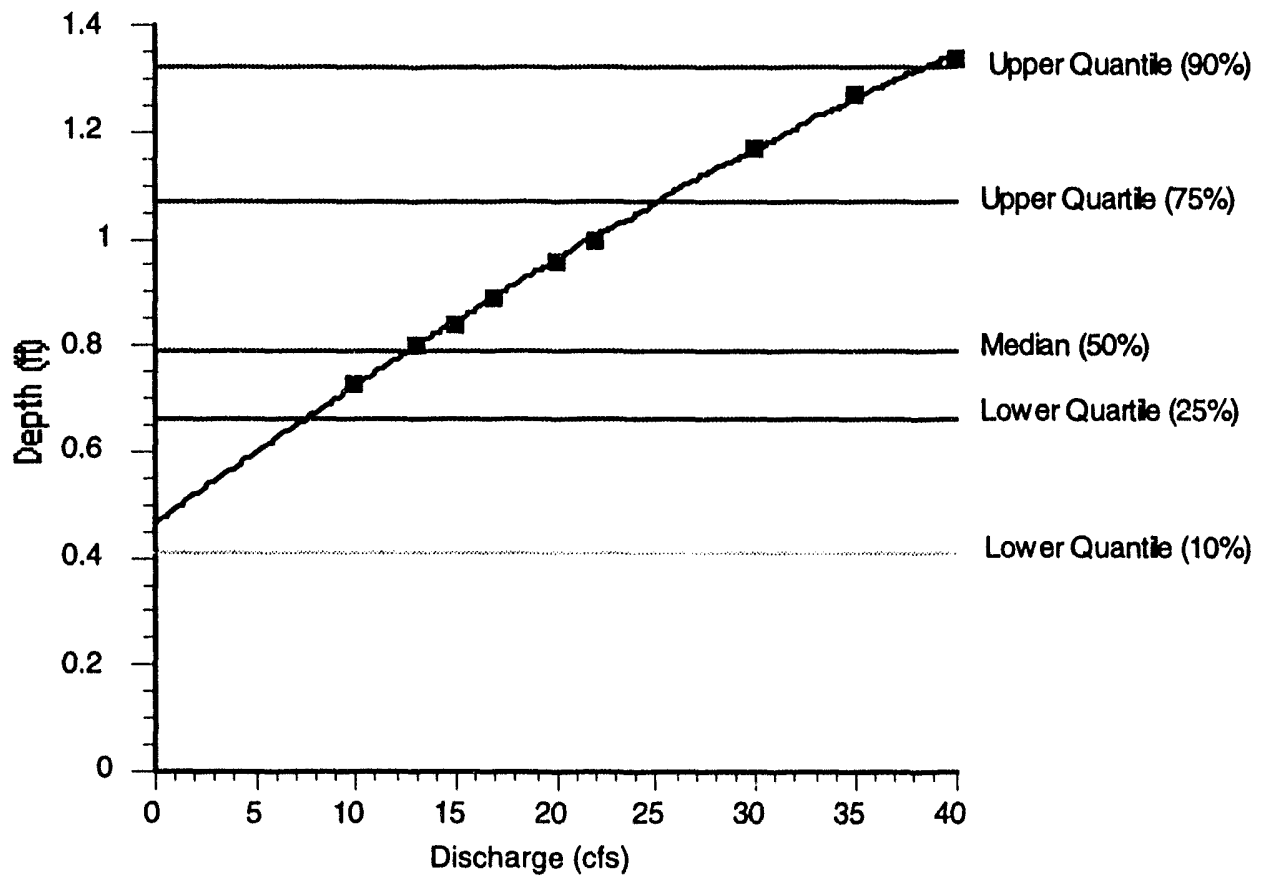

Figure 5. Predicted relationship between discharge and depth in Lower Three Runs at Donora Station. Also shown are median, upper quartile, upper quantile, lower quartile, and lower quantile depths measured during base flow periods in 18 first and second order SRS streams.

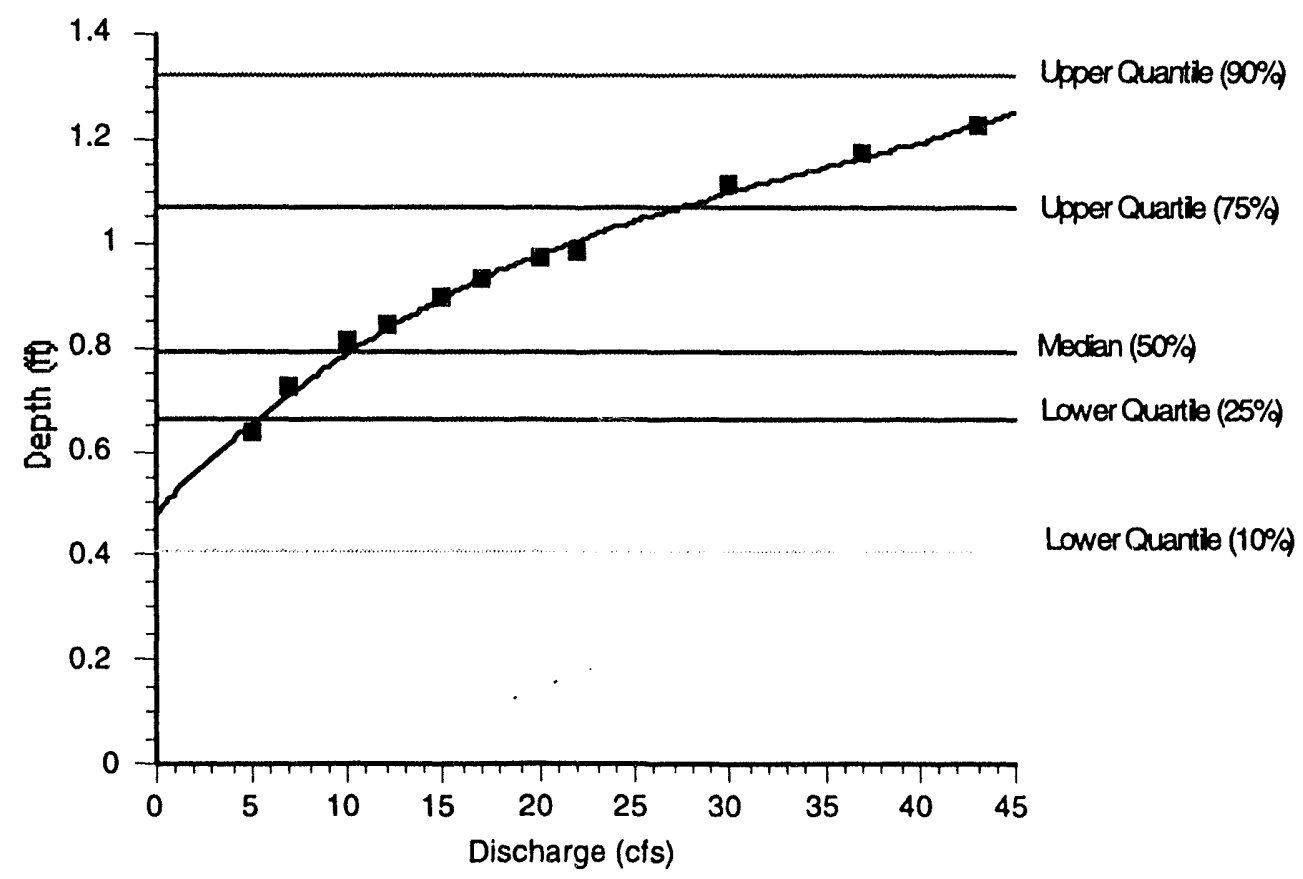


Figure 6. Predicted relationship between discharge and depth in Lower Three Runs at Patterson Mill.

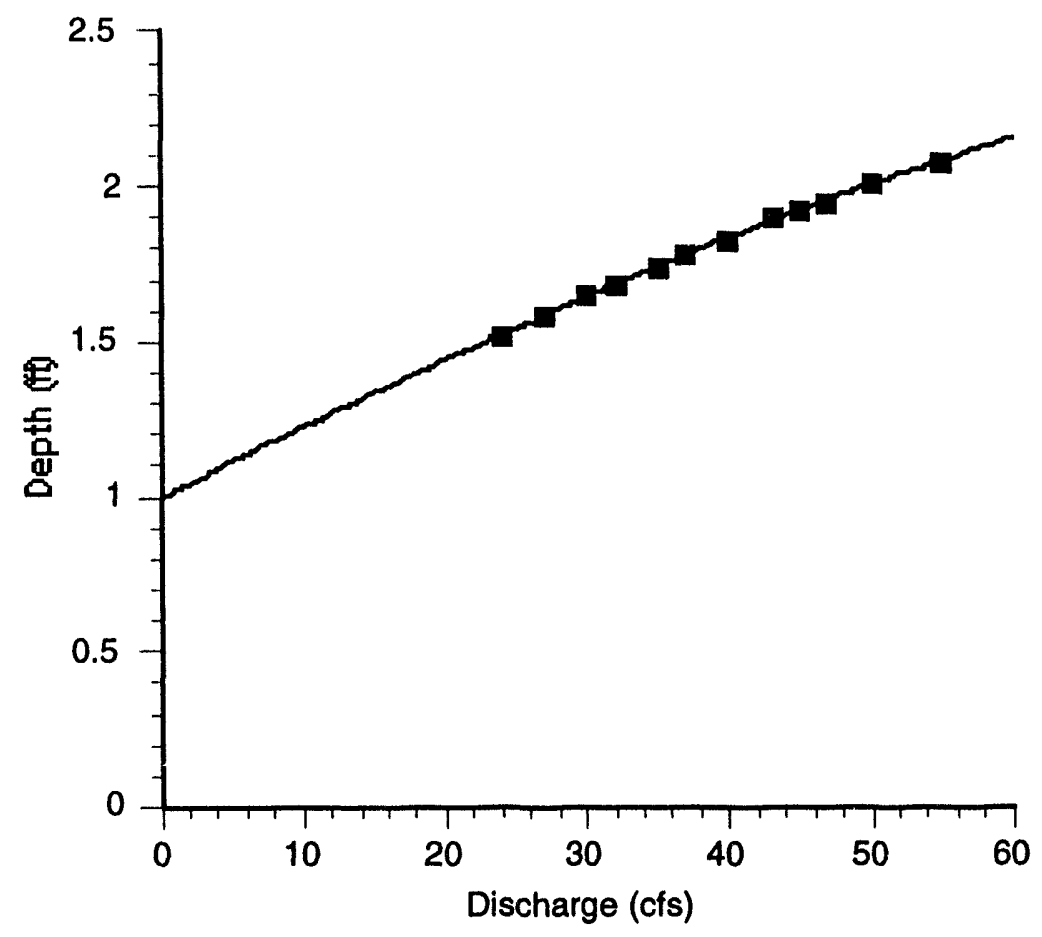

Figure 7. Predicted relationship between discharge and velocity in Lower Three Runs at Road B. Also shown are median, upper quartile, upper quantile, Jwer quartile, and lower quantile velocities measured during base flow periods it. 18 first and second order SRS streams.

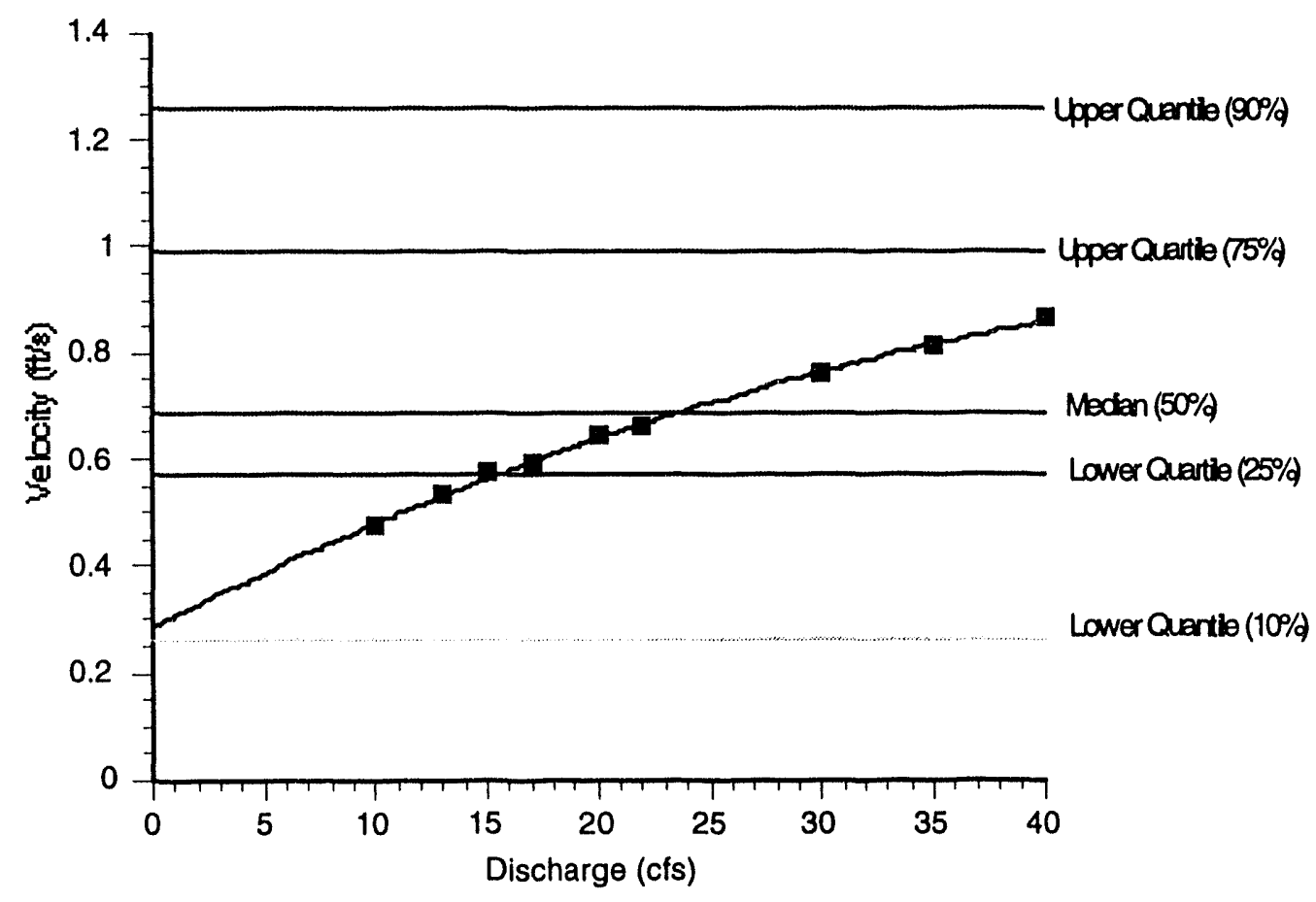


Figure 8. Predicted relationship between discharge and velocity in Lower Three Runs at Donora Station. Also shown are median, upper quartile, upper quantile, lower quartile, and lower quantile velocities measured during base flow periods in 18 first and second order SRS streams.

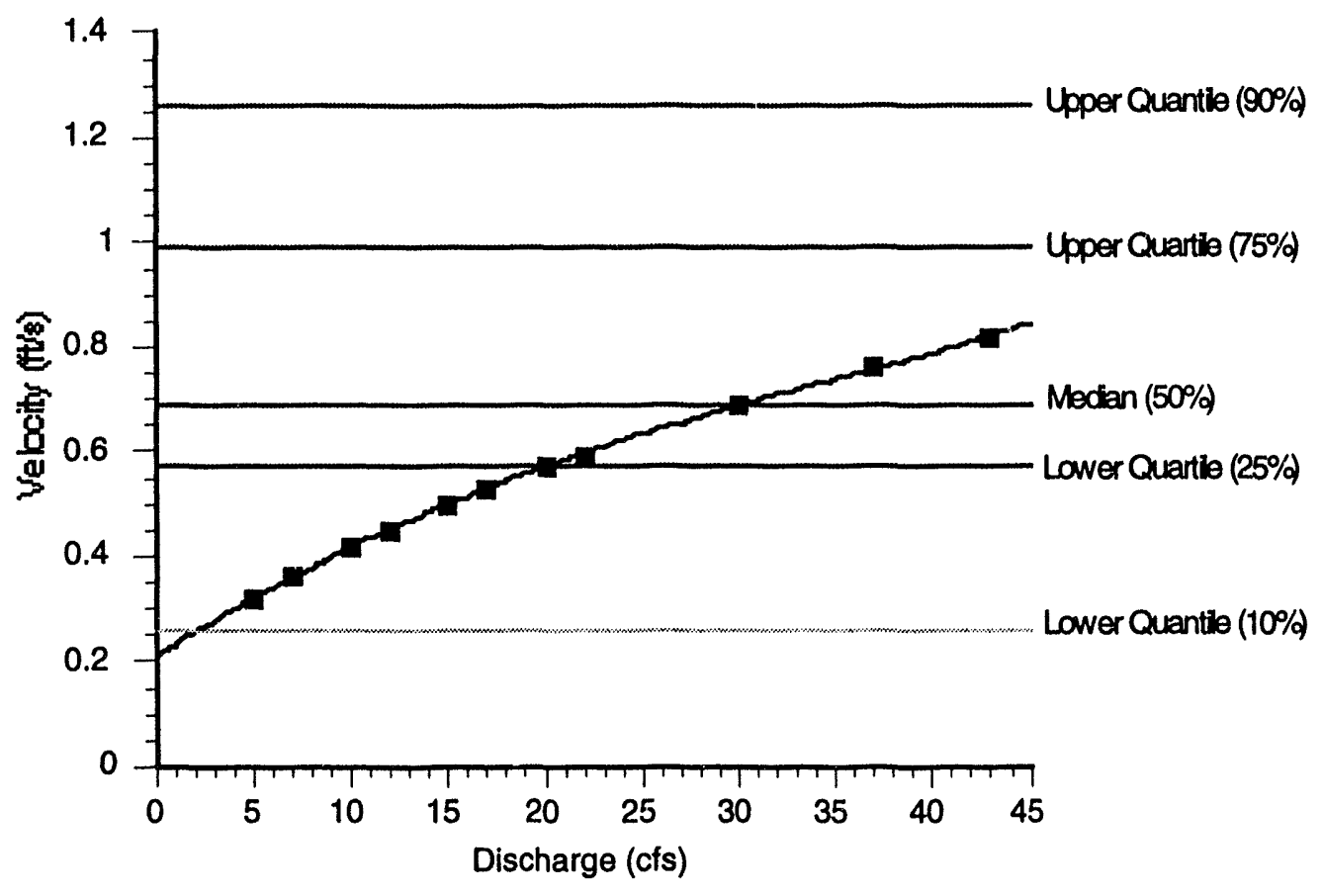

Figure 9. Predicted relationship between discharge and velocity in Lower Three Runs at Patterson Mill.

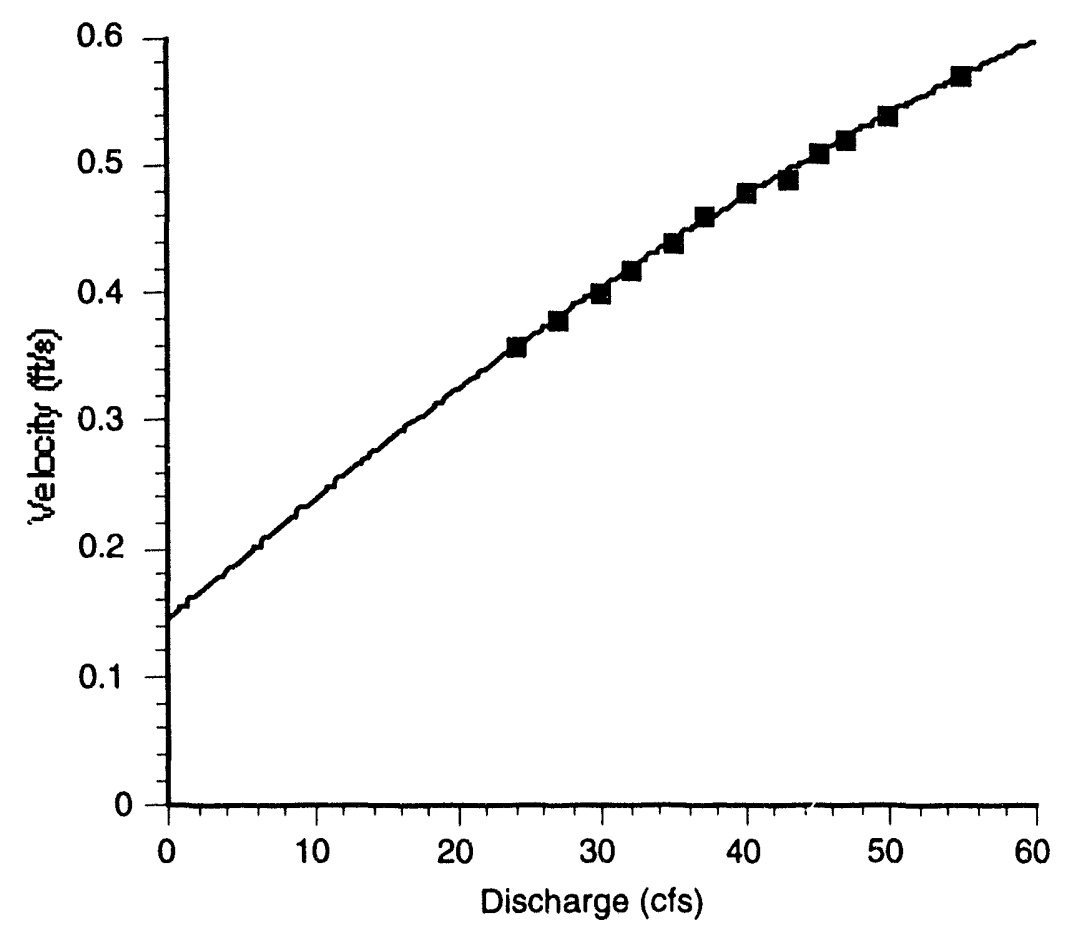




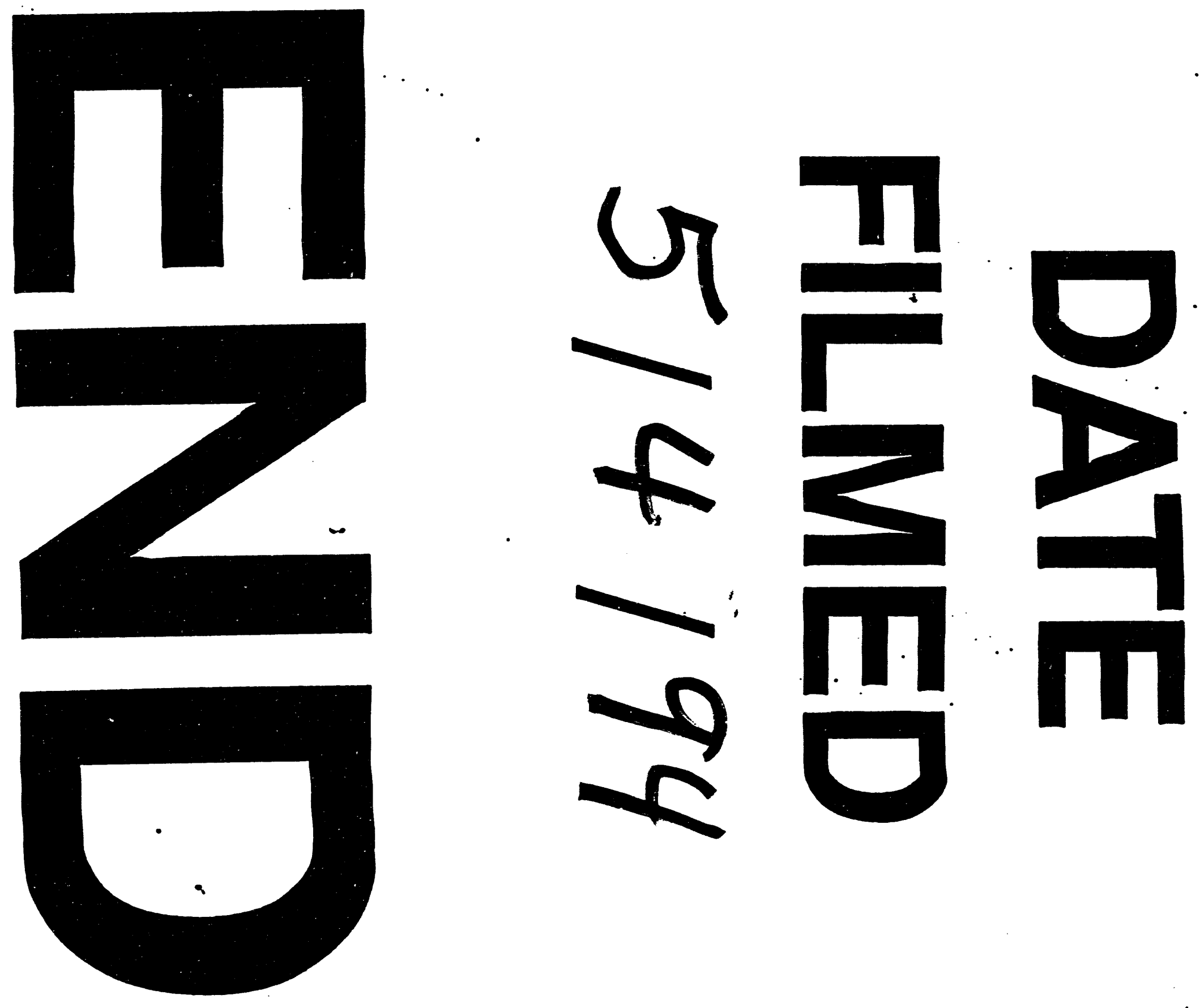


$$
\longrightarrow-
$$

